Iraqi Journal of Industrial Research (IJOIR)

Journal homepage: http://ijoir.gov.iq

\title{
Designing a Decentralized Sewage Treatment Plant
}

\author{
${ }^{1,2}$ Tareq Ahmed Ismaeel* \\ ${ }^{1}$ Renewable Energy and Environment Research Center/ Corporation of Research and Industrial Development/ \\ Ministry of Industry and Minerals/ Baghdad - Iraq \\ ${ }^{2}$ Iraqi Corrosion Center/ Corporation of Research and Industrial Development/ Ministry of Industry and Minerals/ \\ Baghdad - Iraq
}

\section{Article information}

\section{Article history:}

Received: April, 27, 2021

Accepted: May, 24, 2021

Available online: June, 14, 2021

Keywords:

Decentralized Sewage Treatment Plant, IFAS MBBR,

Conventional unit

*Corresponding Author:

Tareq Ahmed Ismaeel

tarikalkaisy@gmail.com

DOI:

https://doi.org/10.53523/ijoirVol8I1ID43

\begin{abstract}
The contamination in Tigress and Euphrates Rivers in Iraq has reached a high level for several reasons; one of these reasons is the discharged of sewage treatment plant (STP) effluent in the rivers, as well as other wastewater treatment plants. But the major problem is to taker discharge of wastewater to the river directly with no treatment! Many tankers in different places in all governorates in Iraq are utilized because of the absence of sewers which collecting the domestic discharge. Wastewater discharge in the rivers increases the pollution levels and especially when the river level decreases during summer seasons. In the last few years, the pollution was dramatically exacerbated. In this paper, an optimum Design for Decentralized Sewage Treatment Plant will be presented. Discharge of sewage tanks in the Tigris River has a severe negative impact on the environment; causing a deficiency in the dissolved oxygen in the water and increasing the limits of toxicity due to the accumulation of organic and inorganic substances. Pollution has become a serious issue that directly affects the aquatic life, agriculture, and people. The design unit has good specifications for effluent water discharge. TSS (Total Suspended Solid) decreased to less than $10 \mathrm{ppm}$, BOD (Biochemical Oxygen Demand) to less than $10 \mathrm{ppm}$, and COD (Chemical Oxygen Demand) to less than $50 \mathrm{ppm}$. The designed unit showed a good and easy operation and maintenance with less chemicals used.
\end{abstract}

\section{Introduction}

The wastewater treatment technology used in Iraq is an old technique that needs large areas because it uses the system of extended aeration which leads to the consumption of large amounts of electricity with high operational costs, and uses chlorine in sterilization, this has a negative impact on environmental life in the river. The modern integrated technology provides ideal solutions in terms of saving space and reducing operational costs, as well as, the high quality of treated water, the degree of purity is similar or higher than the purity of the river water. This 
technology can save approximately $40 \%$ of the same power provided to power a plant of the extended aeration type. This technology also features flexible design characteristics, which can be designed above or below the ground and can be adapted to suit various terrain [1]. This technique also includes the stages of removing carbon and nitrogen compounds, which does not need additional space, because it includes in the Decentralized Sewage Treatment Plant [2].

In this design, the sewage water can be treated and converted into water suitable for irrigation or can be poured to the river as environmentally friendly water. The dry sludge produced by these plants can also be used as organic fertilizers; also we can establish this compact unit in new town and even the location of this unit is not necessarily to be near the river or the town and without sewer network to collect the effluents from houses. The benefit of this unit is easy to construct and easy to remove [3-5].

\section{The Difference between Aerobic and Anaerobic in the Biological Treatment}

To meet the standard discharge effluent and regulations, the biological treatment units usually use the aerobic or anaerobic process in the activated sludge in the large capacity units. This technology has been matured for over a century $[6,7]$.

\section{Aerobic \& Anaerobic}

The aerobic process requires oxygen for treatment. On the other hand, the anaerobic process can operate with the absence of oxygen. Therefore, aerobic treatment process utilizes microorganisms that require oxygen for their metabolism to assimilate organic impurities, converting them into $\mathrm{CO}_{2}$, water and biomass. While the anaerobic processes take place in the absence of oxygen with the aid of different types of microorganisms. The final products of organic assimilation in anaerobic treatment are $\mathrm{CH}_{4}$ and $\mathrm{CO}_{2}$ gases and biomass. The process of aerobic and an aerobic treatment is shown in Figures $(1 \& 2)$ below $[8,9]$ :

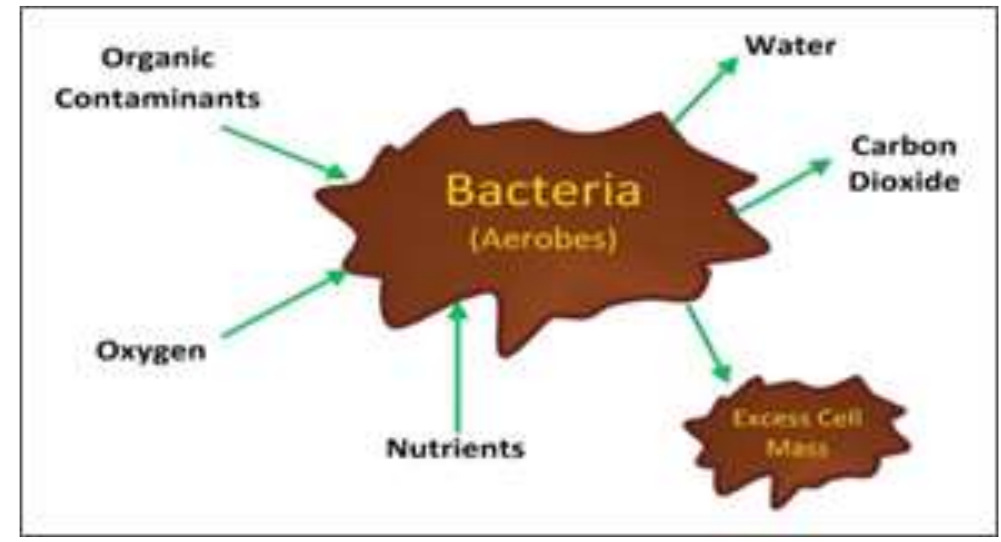

Figure (1). Aerobic Principle.

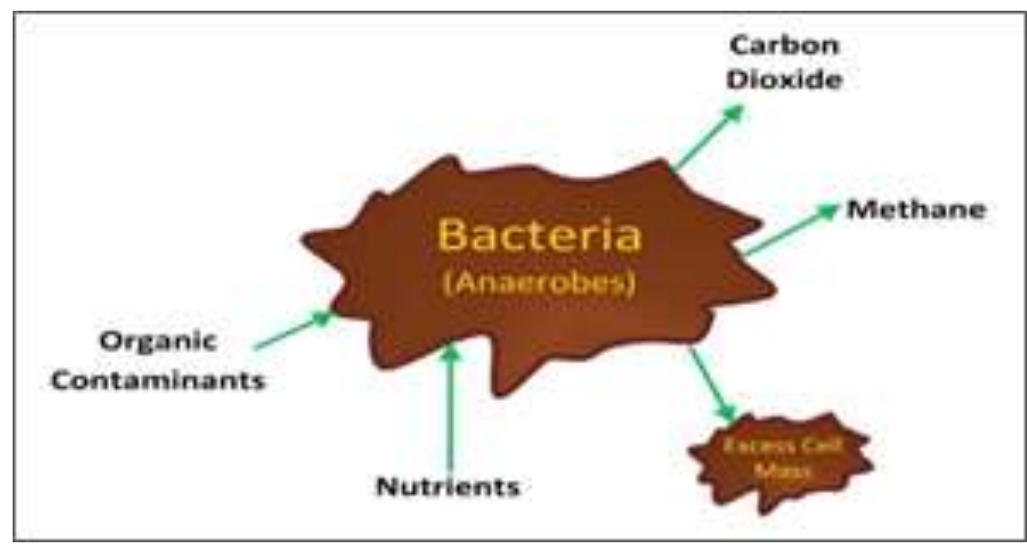

Figure (2). Anaerobic Principle. 
The aeration tank has a diffuser disk to distribute bubbles coming from the bottom of the tank up to the surface of wastewater carrying the oxygen required for the treatment. The diffuser disk receives the air from an air blower to the aeration tank. The returned sludge is meant to activate the microorganisms in the aeration tank $[3,4,6]$.

\section{Overview}

There are different types of wastewater technologies; four of them are the most spread worldwide:

\section{1st - The Treatment is Activated Sludge Process (ASP) System:}

The type of this treatment of wastewater is old and common bio treatment process used for municipal and industrial wastewater. After primary wastewater treatment, the suspended solid impurities are treating in ASP based on biological treatment system comprising tank followed by secondary clarifier. The aeration tank is a completely mixed bioreactor to concentrate either of biomass (measured as mixed liquor suspended solids (MLSS) or mixed liquor volatile suspended solids (MLVSS) and is maintained along with enough dissolved oxygen (DO) concentrate to be $2 \mathrm{ppm}$ to affect biodegradation of soluble organic substances which measure either biochemical oxygen demand (BOD5) or chemical oxygen demand (COD) [10, 11].

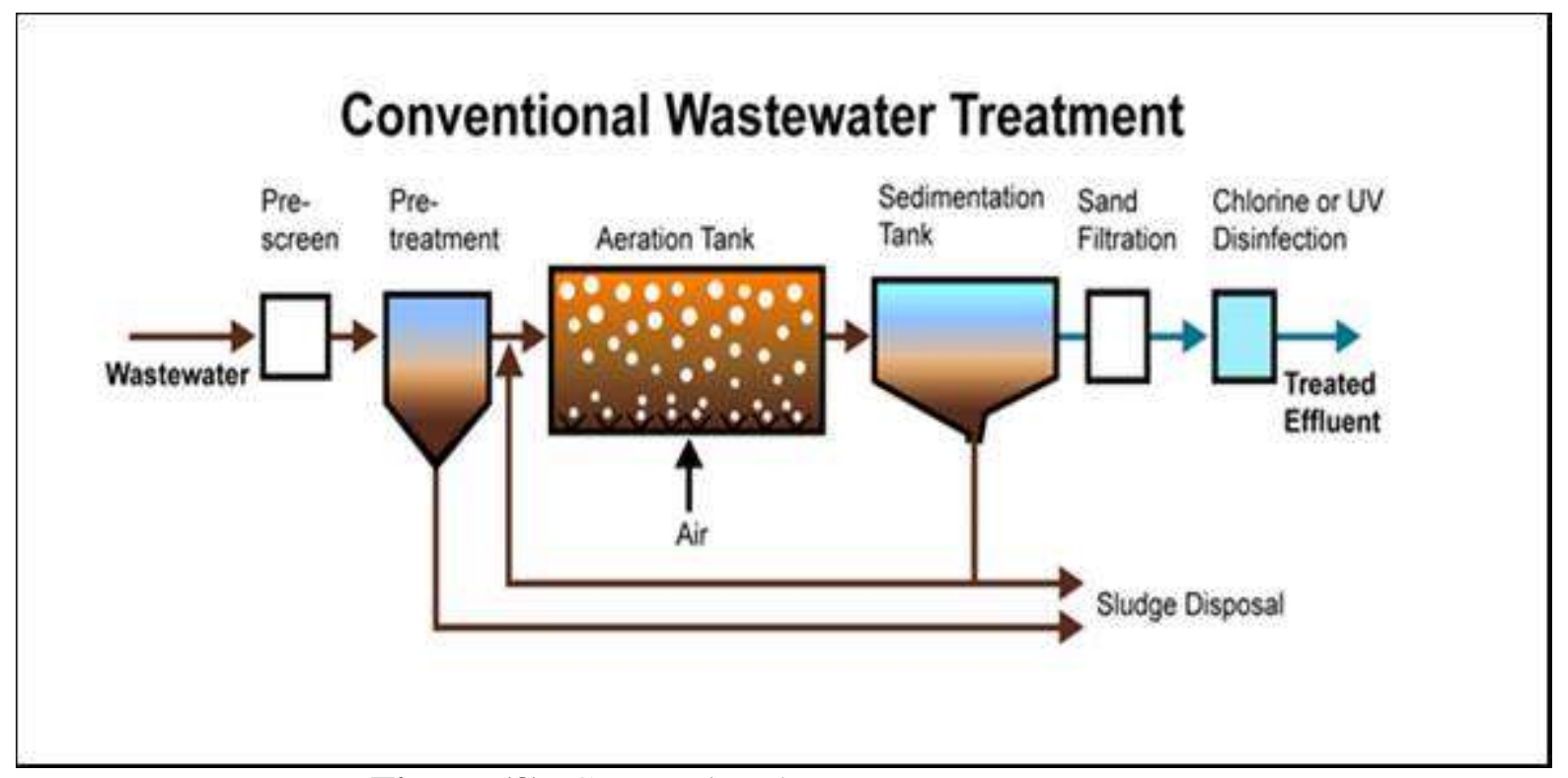

Figure (3). Conventional Wastewater Treatment.

\section{2nd - Cyclic Treatment Activated Sludge System (CASS):}

This system (CASS) is more popular sequencing batch reactor (SBR) processes employed to treat wastewater from municipal and industries such as refineries and petrochemical plants. These technologies have several advantages in operational and performance against the conventional activated sludge process. The CASS, SBR process performs all of the functions of a conventional activated sludge plant by using a single variable volume basin in the treating mode of operation $[1,3,4,7]$. 


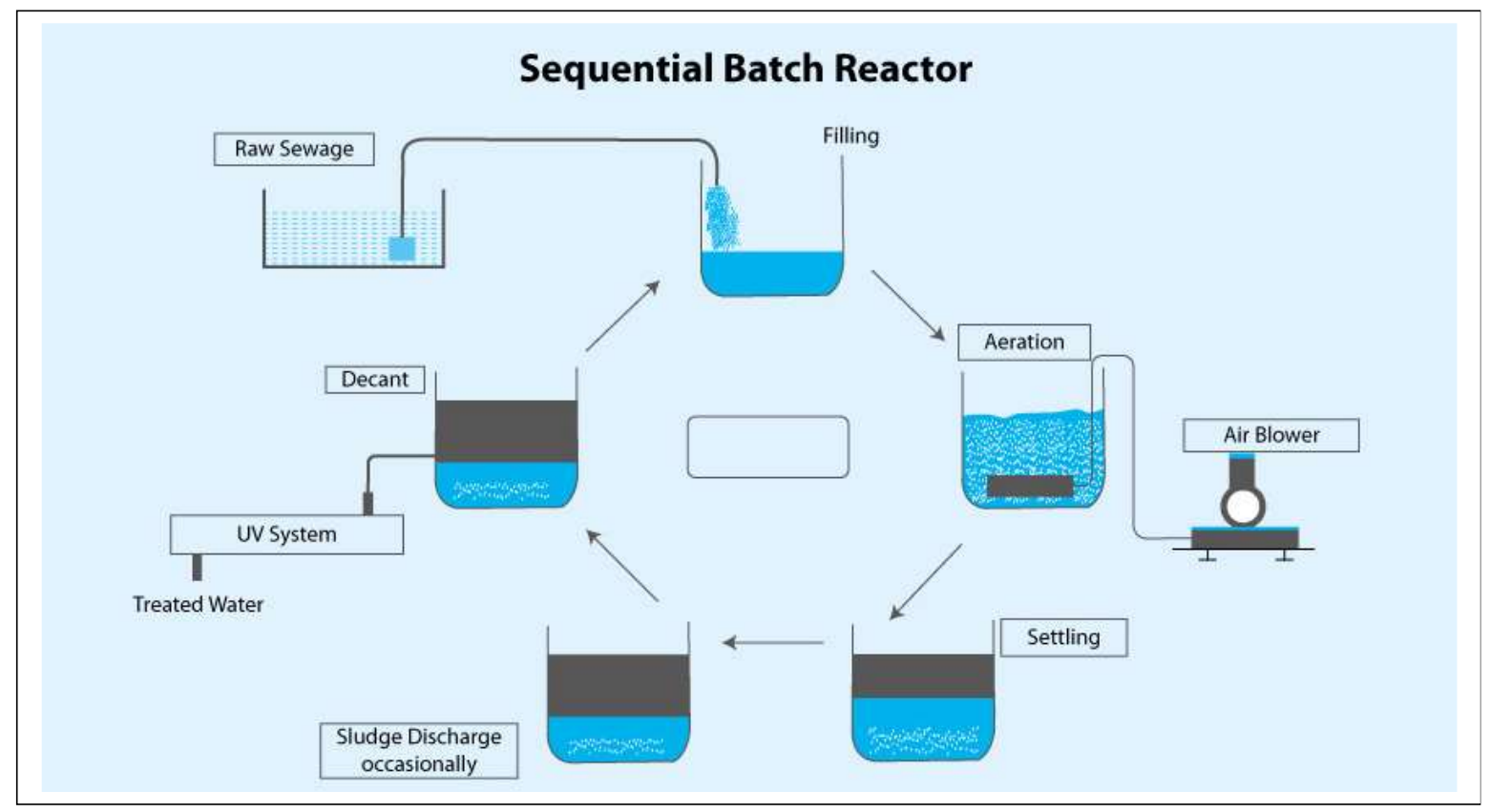

Figure (4). Sequential Batch Reactor.

\section{3rd- The Process of Integrated Fixed Film Activated Sludge (IFAS):}

This type of treatment started using the IFAS process which has two stages of biological treatment refer to plastic media as trickling filter to treat the activated sludge based on aeration tank. Later, there was a developing of above arrangement which used in new industrial wastewater treatment plant is moving bed media bio reactor (MBBR). In some of petrochemical \& refineries plants, the wastewater treatment unit was one stage conventional activated sludge refers to aeration \& clarifier tanks. The upgrading of (ASP) plant capacity by implementing the (MBBR) to meet the new requirements was the choice $[4,5,7]$.

This hybrid process of (MBBR) and (ASP) taking place in aeration tank is now using the new process of Integrated Fixed Film Activated Sludge (IFAS).

The development of conventional activated sludge systems to meet new effluent ammonia or total nitrogen limits is done by incorporating specialized bio-media into portions of the existing aerobic zones to the slower growing bacteria to aid in the reduction of ammonia. The MLSS will degrade the nitrate in pre-denitrification, while the MLSS in aerobic reactors will provide for BOD removal and possible partial nitrification. The use of IFAS system is a cost-effective developed for wastewater treatment plants needing to meet new more stringent effluent limits $[6,7,11,12]$.

The surface area which provided from fixed film media for bio film reduces the resistance of the microorganisms and hence increases biodegradation. IFAS processes are effective in the nitrification of the wastewater more than (ASP).

The benefits of all of the above described process areas below:

High loading rates

Small area and low capital cost

Requires minim new tank age for IFAS upgrade

Reliability 
$>$ Easy of operation

$>$ Compact skid

Designed for future loading

Stable under load variations

The CAPEX \& OPEX of IFAS is lower than other advanced technology such as MBR or AOP.

The IFAS easily used in the existing unit (ASS) to meet the additional processing capacity requirement and the discharge to be with regulations no need to added new concrete tanks $[8,9]$.

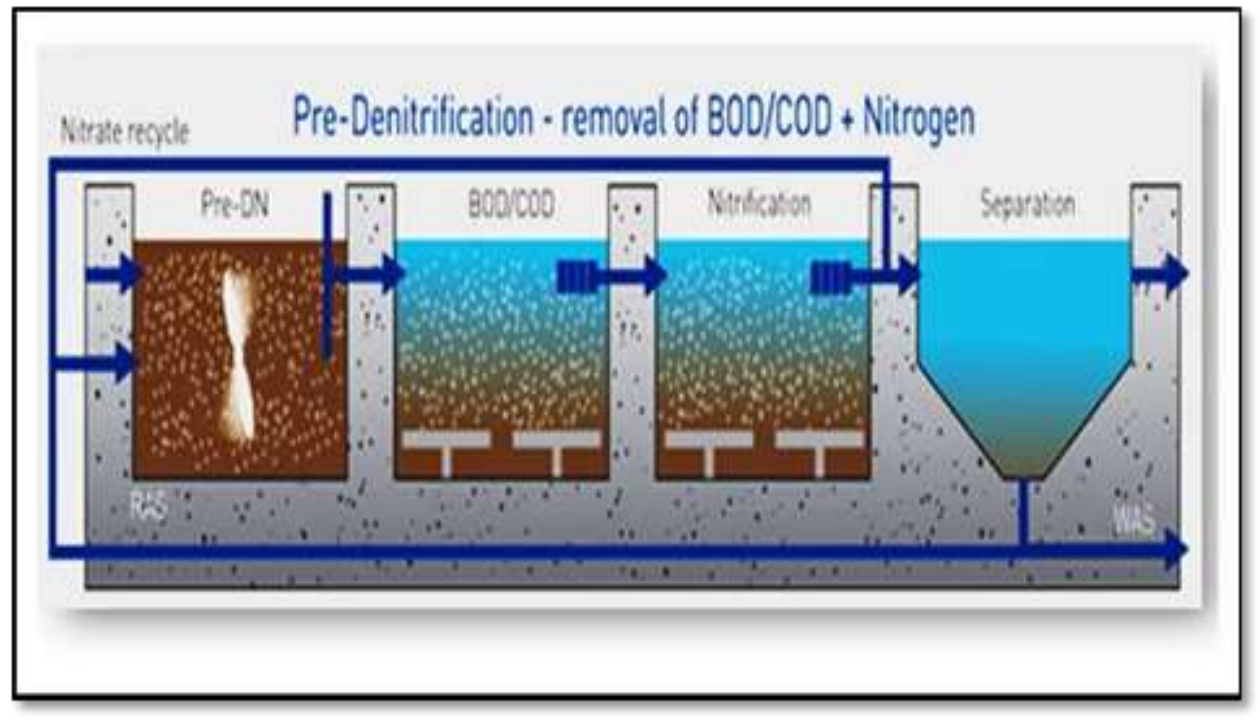

Figure (5). Pre-Denitrification-removal of BOD/COD+Nitrogen.

One of the good examples in the neighbouring countries, the upgrade of phases $4 \& 5$ in Sharjah STP, UAE by using IFAS - MBBR technology. The capacity has been increased from 54000 cubic meters per day to 130000 cubic meters per day (denitrified effluent) by using the existing biological basins [2, 9].

\section{4th-process type Membrane Bioreactor (MBR):}

Membrane bio reactor (MBR) is a process used for biological degradation of soluble organic impurities. MBR has been used intensively in the sewage treatment plants. However, industrial waste treatment has a limited use of this process. The MBR technology is very similar to the ASP in both processes. It is having MLSS in the aeration tank. The advantages of MBR system against traditional activated sludge system are as following: [7, 9].

The good things of Membrane filtration provide a positive barrier to suspended bio-solids, so that they cannot escape the system unlike gravity settling in activated sludge process, where the biosolids continuously escape the system along with clarified effluent and may be loss total of solid. $[10,11]$.

$>$ Due to process upsets causing big sludge in the clarifier tank. So that, the bio-solids concentration measured as MLSS/MLVSS can be maintained at 3 to 4 times in an MBR process (around 10,000 ppm) against to the activated sludge process (around 2500ppm) [6, 8, 9]. 
One can reduce the size of aeration tank in the membrane biological reactor process from onethird to one-fourth the size of the aeration tank in (ASS).

There for the MBR system required just 40-60\% of the space required for ASS, so that the concrete work reduced also overall area required.

The treated effluent quality is far superior compared to conventional activated sludge, so the treated effluent can be directly re used as cooling tower make-up or for irrigation etc.

The treated water quality from MBR systems is BOD5 $<5 \mathrm{mg} / \mathrm{L}$, Turbidity $<0.2 \mathrm{NTU}$, TSS < $0.5 \mathrm{mg} / \mathrm{l}$.

The MBR used in industry wastewater have been successfully referred to treat this wastewater $[11,12]$.

Table (1). General Comparison of biological treatment technologies ASP, IFAS, \& MBR.

\begin{tabular}{|c|c|c|c|}
\hline Parameter & Conventional ASP & IFAS & MBR \\
\hline Treated Effluent Quality & $\begin{array}{l}\text { Meets specified } \\
\text { discharge standards } \\
\text { with additional } \\
\text { filtration step }\end{array}$ & $\begin{array}{l}\text { Meets/ exceeds specified } \\
\text { discharge standards with } \\
\text { additional filtration step }\end{array}$ & $\begin{array}{l}\text { Exceeds specified discharge } \\
\text { standards without additional } \\
\text { filtration step. Very good for } \\
\text { recycle provided TDS level } \\
\text { permits }\end{array}$ \\
\hline $\begin{array}{c}\text { Ability to adjust to variable } \\
\text { hydraulic and pollutant loading }\end{array}$ & Average & Very good & Very good \\
\hline Pretreatment Requirement & $\begin{array}{l}\text { Suspended impurities } \\
\text { e.g. oil \& grease and } \\
\text { TSS removal }\end{array}$ & \begin{tabular}{||c|} 
Suspended impurities \\
e.g. oil \& grease and TSS \\
removal
\end{tabular} & $\begin{array}{l}\text { Fine screening for suspended } \\
\text { impurities like hair and almost } \\
\text { complete oil \& grease removal }\end{array}$ \\
\hline $\begin{array}{c}\text { Ability to cope with ingress of } \\
\text { oil }\end{array}$ & Average & Average & $\begin{array}{l}\text { Poor \& detrimental to } \\
\text { membrane }\end{array}$ \\
\hline $\begin{array}{l}\text { Secondary Clarifier } \\
\text { Requirement }\end{array}$ & Needed & Needed & $\begin{array}{l}\text { Clarifier is replaced by } \\
\text { Membrane filtration }\end{array}$ \\
\hline Complexity to operate \& control & $\begin{array}{l}\text { Simple, but not } \\
\text { operator friendly }\end{array}$ & Operator friendly & Requires skilled operators \\
\hline Reliability of Technology & Average & Very good & $\begin{array}{l}\text { Limited references in } \\
\text { industrial applications or for }\end{array}$ \\
\hline Capital Cost & Low & Average & Very High \\
\hline Operating Cost & Low & Average & Very High \\
\hline Space Requirement & High & Average & Low \\
\hline
\end{tabular}




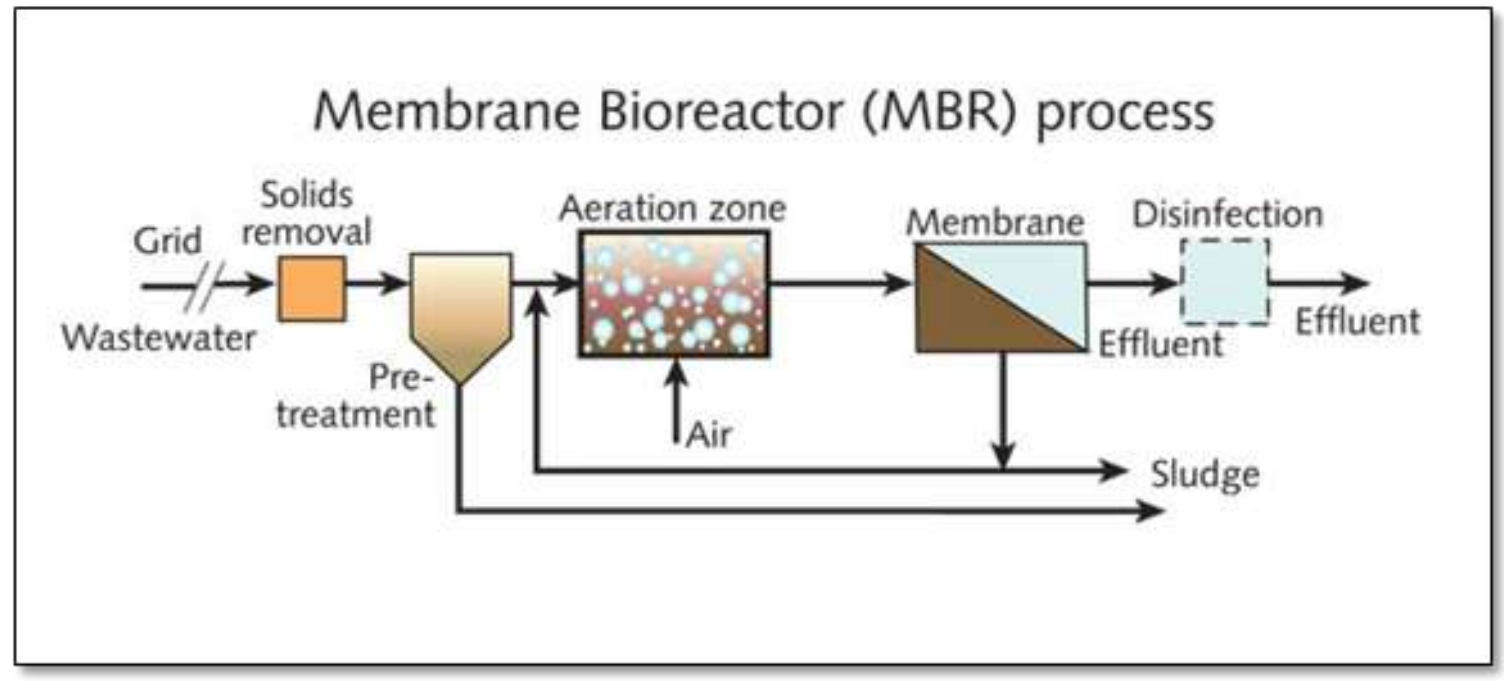

Figure (6). Membrane Bioreactor (MBR) Process.

\section{Process of Biological Water Treatment: MBBR and IFAS Technology}

The engineering of MBBR and IFAS wastewater treatment plants have a lot of difficulties made it not easy to remove. The MBBR process meaning of moving bed bio film reactor, while the meaning of IFAS process is integrated fixed film activated sludge system. The difference between the two processes (IFAS and MBBR) is that in the IFAS system, the activated sludge producing from the sludge recirculation is additionally used, which means that the combination of activated sludge and media bio films is used in the same reaction tank volume. As shown in the figure below: $[10,11]$.
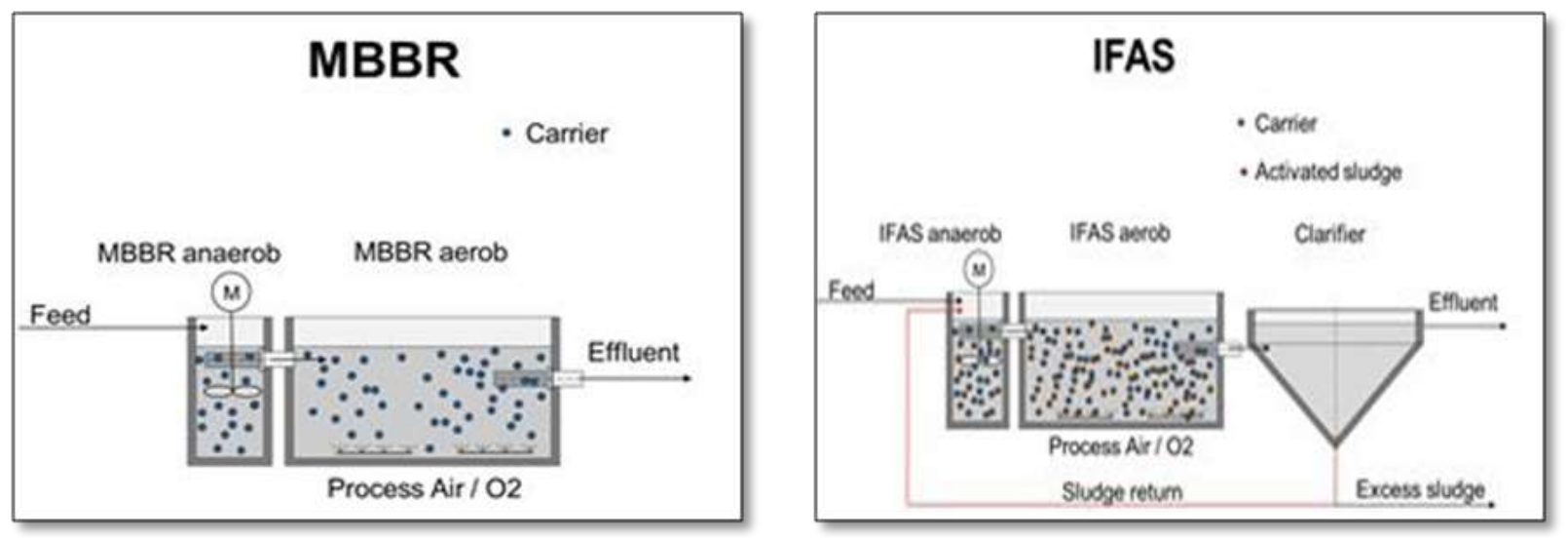

Figure (7). Show the Difference between two processes.

\section{Important Items}

A full study for the site like space condition and details of inlet specifications and the outlet specifications is made. The tank size of the MBBR/IFAS and the media filling rate are calculated based on the pollutant. Quantity of carrier media to be considered of specific product factors of the carrier media. Quality of impurities is calculated from the actual flow $\left(\mathrm{m}^{3} / \mathrm{hr}\right)$ and the respective pollutant concentrations. The main items to specify the dimension of MBBR/IFAS plants are the temperature of wastewater design, yield and product specific removal rates and media chosen $[7,9]$. In the detailed design, the water temperature must be taken in consideration.

If the design temperature is to be high, $\left(35^{\circ} \mathrm{C}\right)$, which means the removal of high flow rate of biological will be taken in the calculation, also the media required and reaction tank volume will be low. The operation plant at normal, the temperature will be lower, for example when the temperature $25{ }^{\circ} \mathrm{C}$, the volume for reaction tank and media quantity will not be enough to complete with the discharge required. It must be added media. But this may not be possible because the maximum media filling rate is between $50-70 \%$ of total $[9,10]$. When the temperature design reduces to $\left(10^{\circ} \mathrm{C}\right)$, the size of tank for the carrier media quantity will be correspondingly larger, there for; 
the water temperature will most likely be higher in practice than assumed for the determined [10, 11]. To consider the optimum design for your IFAS, MBBR plants, it must determine the low and high design temperatures and to make sure that these values have been taken in the calculation [8-10].

It must determine the oxygen requirements for design specification about aeration system. Because the oxygen dissoluble in warm water is worse than in the lower temperature limits. As a consequence, the following general rule applies:

* If the temperature is low, you must calculate the carrier media in the tank.

* If the temperature is high, you must calculate the oxygen supply [11-13].

* Comparison between compact unit \& conventional wastewater treatment

\begin{tabular}{|c|c|c|c|}
\hline 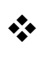 & $\underline{\text { Parameters }}$ & Compact unit & Conventional treatment \\
\hline 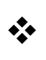 & Initial cost & low & High \\
\hline \& & Space required & low & High \\
\hline 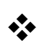 & Chemicals & low & High \\
\hline$*$ & Move the unit & Easy & Difficult \\
\hline & Operating years & More than 15 & More than 25 \\
\hline & Electrical required & Average & High \\
\hline & Secondary clarifier & No need & Needed \\
\hline & Odor removes & Yes & No \\
\hline 8 & Adjust pollutant & very good & Average \\
\hline
\end{tabular}

\section{Basis of Design}

The Sewage Treatment Plant - STP (IFAS MBBR Technology) has been designed to meet the requirements of decentralized wastewater treatment facility \& effluent to be suitable for irrigation or river disposal.

The IFAS-MBBR technology gives a huge reduction in overall area and with small tank, low operation cost, \& easy operating unlike the MBR technology which requires: high power consumption, short membrane service life (around 3 years in best conditions), chemicals consumption for membrane cleaning, high experience to operate the plant $[11,12]$.

Based on wastewater influent parameters and the effluent requirement for BOD/COD and TN removal, the treatment is a seven-stage to remove BOD/COD and TN; the plant capacity is handled in one train. Solids post IFAS shall be handled by secondary \& tertiary treatment. The treatment sequence is consisting of:

1) Tanker discharge Facility (TDF) for 2 tankers per discharge cycle. The TDF includes Fine Screenings, Grit \& FOG Removal Unit.

2) BALANCING TANK (flows equalizing of tanker unloading).

3) PREANOXIC TANK (nitrate \& nitrite removal stage).

4) OXIC TANK (BOD, ammonia, \& organic nitrogen removal combined stage). 


\section{5) DEAERATION.}

6) LAMELLA SETTLING TANK (secondary clarification).

7) TERTIARY FILTRATION (using stainless steel 18-micron mesh gravity filter).

8) FINAL EFFLUENT DISINFECTION (by dosing $\mathrm{NaOCl}$ ).

The IFAS process is refer to integration of bio film carrier technology within the conventional activated sludge process. This hybrid process enables activated sludge systems to achieve dramatic gains in volumetric productivity without increasing mixed liquor suspended solids (MLSS) levels in the process. Moving Bed Bio film Reactor (MBBR) process is a fixed film biological wastewater treatment process. The principle of this technology is based on the bio film, the key component being the carriers in polyethylene high density with a density closer to that of water. The IFAS process employs Refill Tech BIO's proprietary mobile bio film carriers (Refill TECH - SAGM 800) to support a very high concentration of attached biomass; and has excellent mass transfer conditions. Moving freely throughout the liquid [9-11].

In the reactor (basin), the bio carriers provide a highly effective environment for bio film growth and contact with the incoming wastewater. To retain the bio film-carriers elements inside the bioreactors, stainless-steel retention screens are fitted to the tanks' outlets. The screen material is a stainless-steel wedge wire mesh with welded construction. The screens will not require any maintenance for the life of the system [9].

The BOD removal and Nitrifications tank will be operated under aerobic conditions, so that bacteria will consume the TKN in the wastewater while utilizing the oxygen for metabolism and growing the bacterial colonies. Anoxic zone will be maintained in denitrification tank for nitrates reduction [8].

\section{Main Design Objectives}

The Sewage Treatment Plant is in Steel or concrete tanks (according to the site requirements).

Technology introduced is IFAS-MBBR.

Suspended attached growth media: PEHD material; serves life is +20 years.

Continuous TERTIARY FILTRATION - Micro Filtration at low power consumption.

Final Effluent Water is suitable for irrigation or water surface disposal to river (Low Total Nitrogen).

\section{STP DESIGN CRITERIA:}

\begin{tabular}{|cccc|}
\hline Item & Unit & Influent & Effluent \\
\hline PH & -- & $6-9$ & $6-9$ \\
\hline Temp. & ${ }^{\circ} \mathrm{C}$ & $20-35$ & -- \\
\hline TSS & $\mathrm{mg} / 1$ & 350 & $\leq 10$ \\
\hline BOD5 & $\mathrm{mg} / 1$ & 350 & $\leq 10$ \\
\hline COD & $\mathrm{mg} / 1$ & 600 & $\leq 50$ \\
\hline N-NH4 & $\mathrm{mg} / 1$ & 35 & $\leq 5$ \\
\hline TN & $\mathrm{mg} / 1$ & 55 & $\leq 20$ \\
\hline
\end{tabular}


Capacity $=500 \mathrm{~m}^{3} / \mathrm{day}$

Received $=32$ tankers/day Min. $=38$ tankers/day Max.

The STP facilities includes of the following major items:

1. TANKER RECEIVING FACILITY.

2. COMBINED PRETREATMENT UNIT: FINE SCREEN, GRIT \& GREASE REMOVAL UNIT.

3. LIFT PUMP PIT: equipped with duty \& standby pump.

4. BALANCING TANK: equipped with mixers \& feed pumps of average hourly flow pumping.

5. ODOR CONTROL UNIT - ACTIVATED CARBON FILTER (regen able type).

6. PREANOXIC: equipped with duty \& standby mixer.

7. OXIC TANK: equipped with aeration grid, carriers (bio media), \& retention screens.

8. DEAERATION TANK: equipped with internal recirculation pumps.

9. LAMELLA SETTLING TANK: equipped with lamella packs, sludge return pump (RAS), \& excess sludge pump (WAS).

10. GRAVITY MICRO FILTER: tertiary filtration stage.

11. CHLORINE CONTACT TANK (CCT): equipped with final effluent discharge pump.

12. SLUDGE HOLDING TANK: equipped mixer.

13. SLUDGE DEWATERING UNIT: consist of Press Filter, \& cake discharge screw conveyor.

14. Plant room
a) Air blowers 1 duty, 1 standby
b) Chlorine liquid dosing unit (for final effluent disinfection)
c) polymer dosing unit (for sludge flocculation prior to dewatering)
d) Control System

15. INSTRUMENTS magnetic flow meter, PH transmitter, Oxygen dissolved transmitter, TSS transmitter, residual chlorine transmitter; H2S sensor, differential pressure gauge, \& level float switches. 


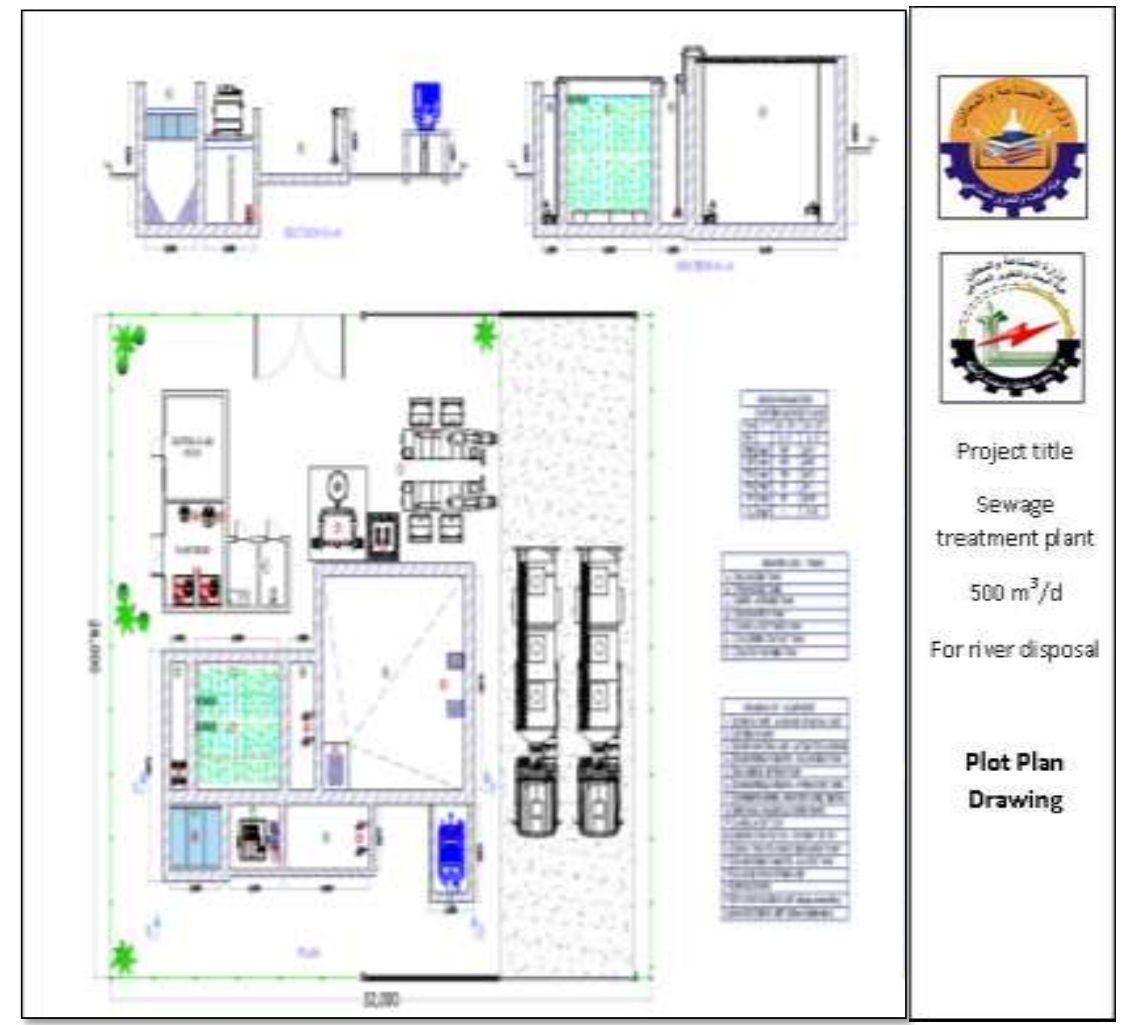

Figure (8). Plot plan drawing.

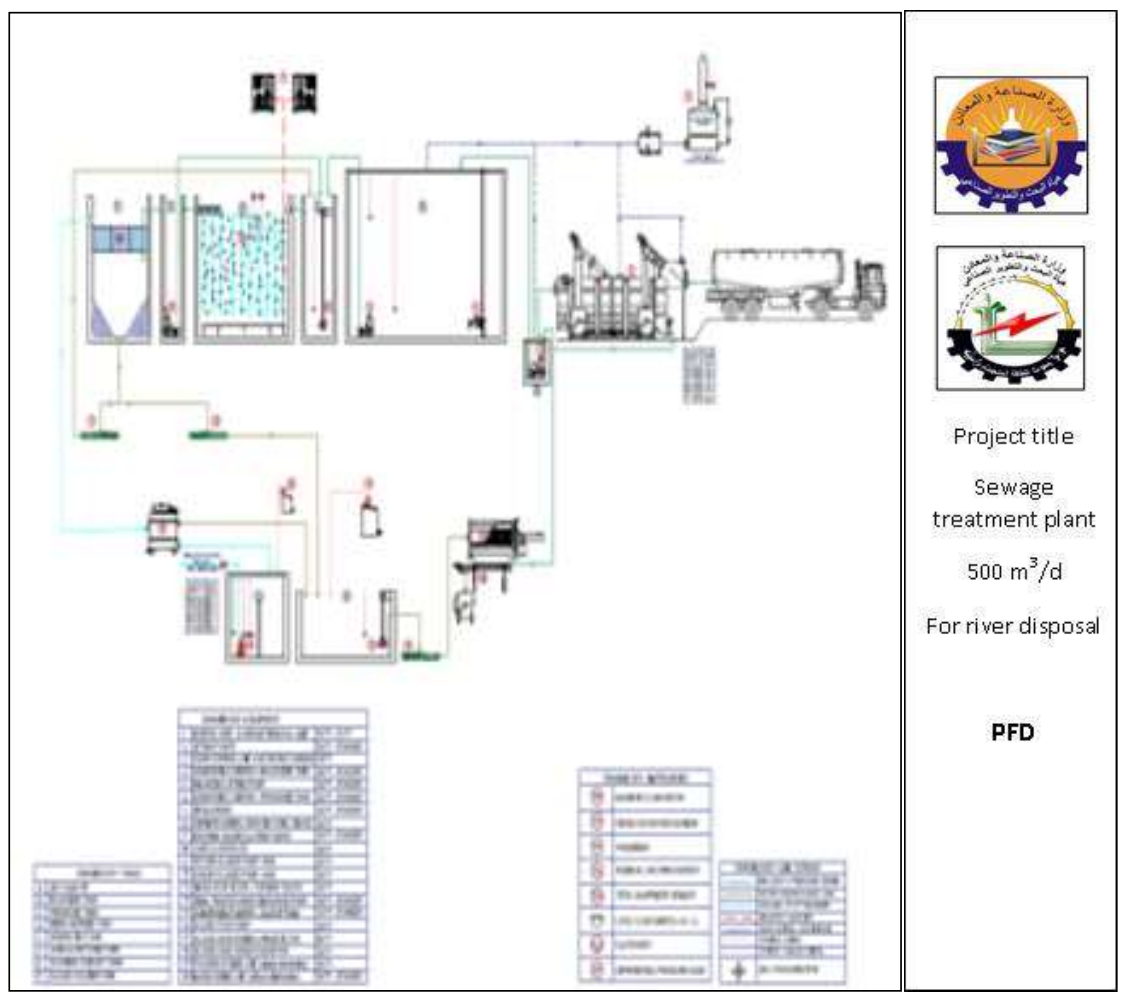

Figure (9). Process Flow Diagram. 


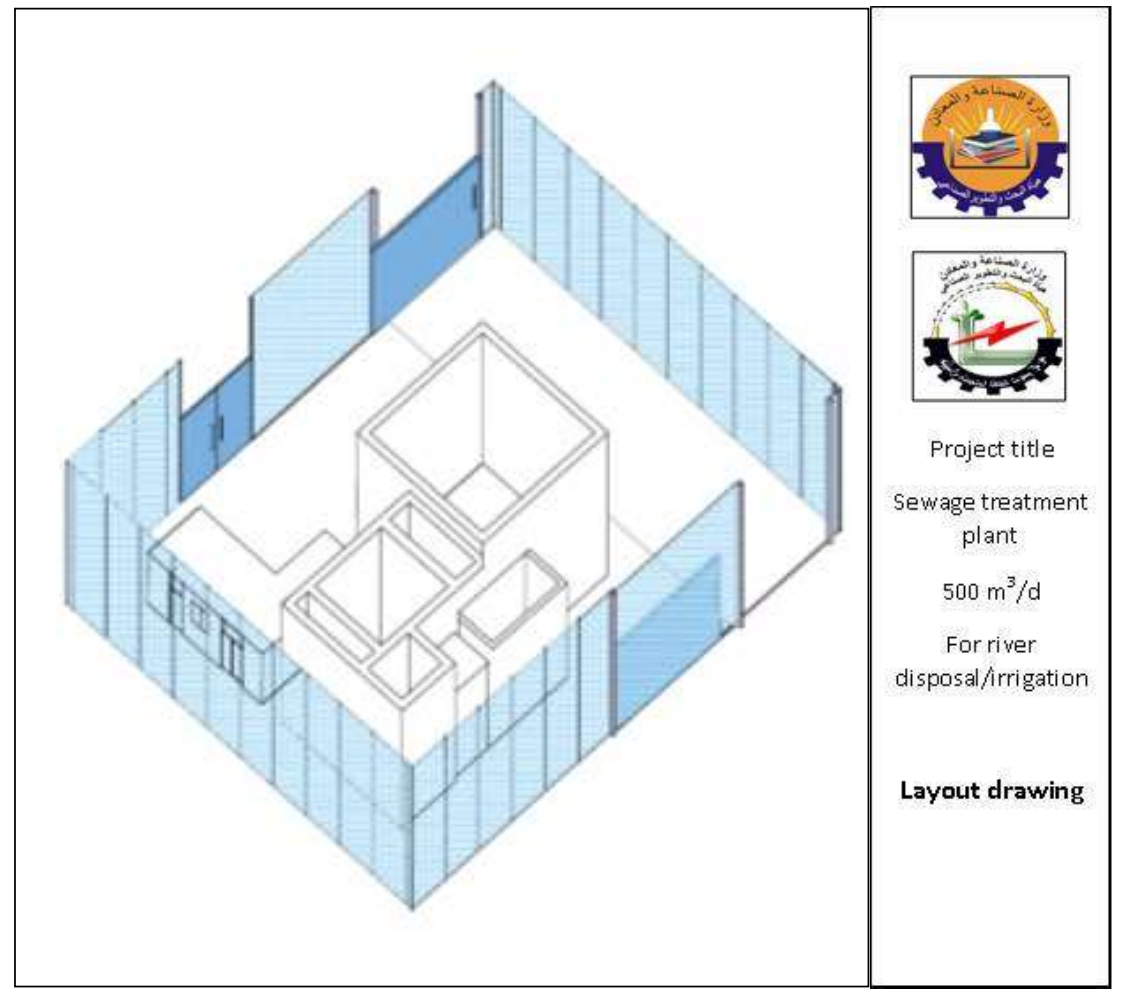

Figure (10). Layout Drawing.

\section{Conclusions}

The preservation of clean river water has become a matter that requires great efforts and amounts to pay for it. Especially in Iraq, the rivers in Iraq cannot be polluted by the dumping of municipal waste in the river.

Therefore, it is necessary to establish decentralized integrated treatment plants for the treatment of this pollution and not to wait until the establishment of large units to treat sewage water, because these units are fast implementation and do not need large areas and consume less electricity than traditional processing units.

On the other hand, many of the tankers contain municipal waste from areas how not serve by network these tankers unload their cargo directly to the river and caused by this polluted water problem for fish, micro-organisms, agricultural and public health

The municipal offices should be establishing the decentralized wastewater treatment unit near the river to stop the tankers discharges the effluent direct to the rivers to obtain clean river in Iraq.

Acknowledgement: I would like to highly acknowledge SIMECO Engineering Co. \& Mr. Faisal Al-Rubaye for their assistance. The Renewable Energy and Environment Research Center is greatly appreciated for the financial and logistic support. I would like to thank Dr. Omar A. Abdulrazzaq for the linguistic assistance.

\section{References}

[1] METCALF \& EDDY. "Wastewater Engineering Treatment and Reus", 4 2004.

[2] B. Van lier, M. Henze, M. C. M. Van Loosdrech, "Biological wastewater treatment principles modelling and design”, IWA, 2008.

[3] I. Navarro, A. Chavez, J.A. Barrios, C. Maya, E. Becerril, S. Lucario and B. Jimenez, "Wastewater Reuse for Irrigation - Practices, Safe Reuse and Perspectives," Intech, Irrigation and Drainage - Sustainable Strategies and Systems, Chapter 2, 2015.

[4] C. Börner, R. Trübenbach, "Application of the MBBR \& IFAS technology in biological water treatment", Filtration + Separation, vol. 54, No. 5, pp. 36-38, 2017.

[5] E. Germain, L. Bancorft, A. Dawson, C. Hinrichs, "Evaluation of hybrid process for nitrification by comparing MBBR and IFAS Configuration," IWA, 2007. 
[6] J. P. Boltz, B. R. Johnson, G. T. Daigger, J. Sandino, "Modeling Integrated Fixed-Film Activated Sludge and Moving-Bed Biofilm Reactor Systems I: Mathematical Treatment and Model Development," Water Environment Research, vol. 81, no. 6, pp. 555-575, 2009.

[7] J. P. McQuarrie1, J. P. Boltz2, "Moving Bed Biofilm Reactor Technology: Process Applications, Design, and Performance," vol. 83, no. 6, pp. 560 - 569, 2011.

[8] Hallvard Ødegaard "Compact wastewater treatment with MBBR," NTNU, 2014.

[9] B. R. P, Gulhane M. L, and K. A. J, "Moving Bed Biofilm Reactor - A New Perspective in Wastewater Treatment," vol. 6, Issue 6, PP 15-21, Nov. - Dec. 2013.

[10] A. Malovanyy, J. Trela E. Plaza, "Mainstream wastewater treatment in integrated fixed film activated sludge (IFAS) reactor," 2015.

[11] L. Biosen Staal, and A. Boisen Peterrsen, and C. A. jorgensen, "Extraction and quantification of polyphosphates in activated sludge from waste water treatment plants by 31P NMR spectroscopy," Water Research, vol. 157, no. 15, p. 346-355, 2019.

[12] I. Singha, and P. Kumar, "Nano-membrane filtration a Novel Application of Nanotechnology for Waste Water Treatment," Materialstoday, vol. 29, part 2, p. 327-332, 2020.

[13] M. Sridevi, C. Nirmala, and N. Jawahar, "Role of nanomaterial's as adsorbent for heterogeneous reaction in waste water treatment," Journal of Molecular Structure, vol. 1241, p. 130596, 2021. 